\title{
From Urban Political Economy to the Cultural Political Economy: Rethinking Culture and Economy in and beyond the Urban
}

\section{Running title:}

From Urban Political Economy to the Cultural Political Economy:

Ramon Ribera-Fumaz

Estudis d'Economia i Empresa

Universitat O berta de Catalunya

Av. Tibidabo, 39-43

08035 Barcelona

Email: rriberaf@ uoc.edu

Tel. +34 932542169

(7,402 words, excluding references)

Acceptat però demanat petits canvis 


\section{Acknowledgements}

I am very thankful to Bob Jessop, Noel Castree and G reig Charnock for constructive and very helpful comments on earlier drafts. Of course, I am solely responsible for any errors or mistakes in this paper. 


\title{
From Urban Political Economy to the Cultural Political \\ Economy: Rethinking Culture and Economy in and beyond the Urban
}

\begin{abstract}
Discussions about the culture-economy articulation have occurred largely within the confines of economic geography. In addition, much attention has been diverted into caricaturized discussions over the demise of political economy or the invalidity of culturalist arguments. Moving the argument from the inquiry on the "nature" of the economy itself to the transformation of the role of culture and economy in understanding the production of the urban form from an urban political economy (UPE) this paper focuses on how the challenges posed by the cultural turn have enabled urban political economy to participate constructively in interdisciplinary efforts to reorient political economy in the direction of a critical cultural political economy.
\end{abstract}

Keywords: Culture and economy, urban geography, urban political economy, economic geography, cultural political economy 


\section{Introduction}

O ne of the most vivid outcomes of the post-modern/ cultural turns 1 in Anglo-American 2 human geography has been the long-running debate over the role of political economy in the discipline (Jones, 2008; A min and Thrift, 2007a, 2005, 2000; Harvey, 2007; Smith, 2005; G oodwin, 2004). This debate has been intensely reflected in the long-running discussion over the articulation between culture and economy. The discussion that has emerged from within a new field of 'cultural economy'3 has been characterised by a twofold barrier to progress regarding our understanding of the culture-economy articulation. First, the discussion has been characterized by crude caricatures of culturalists as die-hard absolute relativists, and of political economists as irreducible basesuperstructure materialists. Second, the discussion has been limited in much of the literature to the confines of economic geography, despite its inherently 'more than economic' subject matter. ${ }^{4}$

In this context, there are an increasing number of interventions, incorporating new and interesting questions, theories and methods from the cultural turn, that attempt to find an appropriate balance between positions concerning the relations of culture and economy that go beyond the divide between culturalists and political economists (compare Gregson et al, 2001 with Castree, 2004 and Barnes, 2005). Y et, from a political economy perspective, there are still concerns that the cultural turn has accompanied an abandonment of old but perhaps still relevant questions, such as inequality, uneven development, and the normative character of political economy analysis (Jones, 2008; Coe, 2006; Hudson, 2006; Martin and Sunley, 2001).

Rather than write another individual intervention advocating the superiority of either culturalism or political economy, or looking for a third way, the aim of this paper is to contribute to recovering "a sense of political economy through post-disciplinary 
expeditions to capture 'new intellectual currents,' whilst emphasizing some 'fundamental continuities within the make up of contemporary capitalism"' and as regards our understanding of the articulation between culture and economy in particular (Jones, 2008: 2 following Martin and Sundley, 2001 and Goodwin, 2004)

To accomplish this, first, I will reframe the starting point of the discussion from the inquiry on the "nature" of the economy itself to the transformation of the role of culture and economy in understanding the production of the urban form from an urban political economy (UPE) perspective. If political economy utterly dominated one field in the 1970s and 1980s, this was the study of urban restructuring - and allegedly prone to economicism for this very reason. However, the cultural turn has not signified an entrenchment of positions, but as recent interventions in this journal have already amply demonstrated, developments - at least within urban geography - can chart a route for tackling more sophisticated and balanced approaches to the articulation of culture and economy for human geography more generally (see Lees, 2002; Latham and McCormack, 2004). In this sense, I will argue that there exists a small but growing body of work in UPE which, rather than representing a reactionary defense against the cultural turn, has started to critically and constructively rethink the culture-economy articulation. By drawing on UPE, I will illustrate the transformation of political economy in the last decade.

D ecisively, this review aims not only to recover culture for political economy (i.e. the importance of paradigm shifts and new cultural constructions in the material transformation of urban form and urban politics), but also to reflect critically on the political economy categories deployed. G oing one step further, therefore, I will argue that these efforts occur at the same time, and can be connected to, others' attempts made outside geography to move from political economy to cultural political economy (CPE). Thus, this intervention not only aims to contribute to the mapping of new urban political 
economies, their progress and agendas, but also to elaborate their implications for political economy in human geography.

In section II, I will outline the main characteristics of UPE before the early 1990s. Section III presents the main factors that have allowed some political economists to introduce culture into political economy in a more constructive manner. Section IV then argues that, by looking holistically at a series of individual works developed within UPE but which are not necessarily interrelated, we can observe the rise of a different approach to political economy that not only brings culture to the center of the analysis, but also takes seriously the challenges posed by the cultural turn. In section $\mathrm{V}$, I will suggest that these works in UPE can fruitfully be read in conjunction with other literatures from outside human geography in order to build a cultural political economy (CPE) analysis that reconciles concerns for the immaterial and the material without reproducing the often dogmatic postures to which radical postmodernism and orthodox political economy too often resort. Finally, in section VI, I provide some reflections on the possible contribution to be made by CPE for urban, and, more generally, human geography.

\section{N ew urban politics, a political economy of the city}

Before the 1960s, urban studies were mostly influenced by the work of the Chicago School of Urban Ecology, which developed during the inter-war period. Its approach was strongly based on the urban morphology of Chicago and other American cities but quickly expanded its influence and cross national and disciplinary borders, having a critical influence in the development of urban studies in both sides of the Atlantic (cf. Claval, 1998 with Savage et al, 2003). In the 1960s, when urban geography became consolidated, the sub-discipline was in the vanguard of the quantitative revolution. Nonetheless this revolution did not substantially change the principles set by the Chicago 
School but reoriented them from a descriptive to scientific analysis methodology, and on this basis, to predict and solve city problems (for a review see Zukin, 1980; Savage et al, 2003).

However, events such as the uprisings of the "ghettoised" Afro-American population in the US and the taking of the streets by Parisian students in May 1968 signalled the arrival of new urban problems. The post-war $\mathrm{G}$ olden $\mathrm{Y}$ ears could not eradicate "urban" problems- rather, they created them. Poverty, deprivation and inequality became visible with the 1960s uprisings (Zukin, 1980). In this frame, the 1970s saw the gradual emergence of political economy as the dominant approach in urban studies. The consolidation of UPE also was determined not least by the great impact of David Harvey's (1973) Social Justice and theand Manuel Castell's U rban Q uestion (first its French version of 1972 and then the translated one in 1977). In addition, policy transformations began from different positions and evolved at different speeds at each side of the Atlantic. The work undertaken in Europe differed markedly from that in North America. While new European radical geographers applied new approaches to understand the inability and fall of Keynesian modes in managing the crisis, North Americans focused on understanding the increasing emphasis in local politics on promoting economic growth. For, as supply-side economic policies were more widely adopted at the end of the 1980s, what came to be known as the new urban politics (NUP) was increasingly identified with the promotion and, indeed, in many cases, the celebration of "entrepreneurialism." Critically, the integration of this policy shift into urban scholarship was due to the impact of David Harvey (1989a: 8; see also Leitner, 1990), who defined entrepreneurialism as 'a public-private partnership focusing on investment and economic development with the speculative construction of place rather than amelioration of conditions within a particular territory as its immediate (though by no means exclusive) political an economic goal.' 
Henceforth NUP and entrepreneurialism have been treated as interchangeable equivalents to refer to the politics of place promotion, competitive marketing, flagship events, downtown development and a host of other projects to attract investment and promote economic growth (Jonas and Wilson, 1999a; Hall and Hubbard, 1998). ${ }^{5}$ Compared with earlier approaches in urban studies, this reorientation had three interesting features. First, there was something "new" in the real world: a shift in urban policies. Second, this was reflected in 'the widespread acceptance that urban politics can no longer be analyzed in isolation from the larger political and economic forces that shape the development, restructuring, and redevelopment of urban spaces and places' (Jonas and Wilson, 1999b: 11). Third, this prompted serious efforts to critically reflect on the analytical categories that had been used in previous work on the urban and in political economy (e.g. Harvey, 1973; Castells, 1977).

Moreover, although UPE is no longer as dominant in contemporary urban studies as it was in the 1980s (table 1), the study of entrepreneurialism has continued to dominate geographical analysis of urban politics in the 1990s and beyond. ${ }^{6} Y$ et, this has also meant that the study of "entrepreneurialism" has thereby come to represent the epitome of the reductionism of urban processes to economic materialism (cf. Barnes, 2003, 2005; McN eill, 2003). On this basis, although UPE had, to be surer, largely avoided cultural concerns in the 1980s, many political economists in urban studies have since become far more aware of culture than was characteristic of their economic geography counterparts during the 1990s.

\footnotetext{
*** Table 1 around here $* * *$
} 


\section{Inserting culture in urban political economy}

The cultural and postmodern turns in human geography have had an important general impact on the culturalist shift in UPE. Here I want to focus on three changes in particular that have influenced this reorientation in urban studies. First, there is the appearance of the (postmodern) Los Angeles School, whose cultural turn in the study of the urban was mirrored by an urban turn in cultural geography (cf. D ear, 2003 with Barnes, 2003). Second, as culture has become a more explicit part of economic urban strategies (e.g. European Capitals of Cultures; the Guggenheim effect, ${ }^{7}$ etc.), urban political economists also started to think seriously about the role of culture and discourses in the production of urban strategies. Third, new studies in political economy more generally during the 1980s and early 1990s provided new tools to incorporate culture into the analysis (see section III.3 below). All these processes have made political economy more permeable to culture in the field of urban studies than in its economic counterpart.

\section{From Chicago to Los Angeles}

For many, the political economy crisis of the Keynesian regime not only the end of the post-war politico-economic order but also the end of the modernist experience in all its facets: aesthetical, cultural, social and scientific. Though the challenges to modernism came from very different and complex routes, they can be linked under the terms of cultural and postmodern turn, as contesting the established understandings of the world since the enlightenment. Postmodernity claimed the death of modernity and its cultural forms, its political economy, and its rationalities. As Jencks (1992: 11) concludes, 'postmodernism means the end of a single world view and, by extension, "a war on totality," a resistance to single explanations, a respect for difference and a celebration of the regional, local and particular.' From a postmodern perspective, then, it follows that 
UPE - a top-down, universalistic, single view of the world - cannot explain the local and the particular. Hence, as D ear (2000: ix) suggests,

[a]nalogously, in postmodern cities, the logics of previous urbanisms have evaporated; absent a single new imperative, multiple forms of irrationality clamor to fill the vacuum.

The localization (sometimes literally the concretization) of these multiple effects is creating the emerging time-space fabric of what may be called a postmodern society.

In a nutshell, postmodernism both represents and "represents" the end of an actually existing cultural political-economic form - the modernist city - and of the modernist ways of understanding it. This shift in understanding the world had three major impacts. First, it challenged the well-established modern assumption that culture is subjugated by, or epiphenomenal to, the economic - an assumption shared by political economists and positivists alike. Second, bringing culture to the city prompted a new culturally-influenced urban geography, thus, breaking the rural character of Sauerian cultural geography (Barnes, 2003). Third, in addition to this reinstatement of culture, the postmodern society was seen as essentially urban, that is, located in the city (D ear, 2000). In other words, rather than studying urban social change from above - in line with the modernist privileging of (global and national) space over place, it recommended exploring social change from below - thereby emphasizing that place dominates over space (see Agnew, 2005). This new urban society allegedly has a different urban form from the modernist city. If modernism has been symbolized by $19^{\text {th }}$ century Paris and early $20^{\text {th }}$ century Chicago, the postmodern city is seen from two very particular places, Los Angeles and 
Las Vegas, and through the particular view of the "Los Angeles School" (see Scott and Soja, 1996; Curry and Kenney, 1999; D ear, 2002, 2003). What Los Angeles represents

Like all cities, is unique, but in one way it may typify the world city of the future: there are only minorities. No single ethnic group, nor way of life, nor industrial sector dominates the scene. Pluralism has gone further here than in any other city in the world and for this reason it may well characterize the global megalopolis of the future (Jencks, 1993:7; quoted in Dear, 2003: 499).

Thus, no wonder that the markedly urban character of postmodernism with the consolidation of new cultural geography has had a huge impact in urban geography as well as in challenging UPE's economicistic understanding of the urban.

\section{The culturalization of entrepreneurialism}

As cities, and ways of understanding them changed, urban politics have been changing too. E ntrepreneurial strategies have evolved from "crude" supply-side policies aimed at the speculative construction of place (see section I) towards a more sophisticated Schumpeterian understanding: 'the creation of opportunities for surplus profit through "new combinations" or innovation' (Jessop, 1997: 79). Strategies must enhance innovation and be innovative themselves. Crucially, innovation depends on dynamic urban cultural fabrics.

Projects like Bilbao's G uggenheim Museum are bringing culture to the heart of urban economic strategies. This also involves a more holistic vision between culture and economy (Landry, 2000; Chatterton, 2000). This new vision understands cultural factors 
as the key to the wealth of cities, both economically and socially. The city is economic and socially inclusive in two ways. First, joining explicitly economic and social goals,

the increasing importance of creativity, innovation, and knowledge to the economy opens up the social space where more eccentric, alternative, or bohemian types of people can be integrated into core economic and social institutions. Capitalism, or more accurately new forms of capitalist enterprise (i.e. the R\&D lab and the startup company), are in effect extending their reach in ways that integrate formerly marginalized individuals and social groups into the value creation process' (Florida, 2002: 57).

In this context, culture is understood both as the industries that produce the immaterial and as the representations and symbols that produce the environment where creativity can grow (Zukin, 1995; O 'Connor, 1998; Scott, 2001). Thus, it is not only important to develop the increasingly important cultural content industries but also to develop the particular cultural environments where the creative classes can be developed (i.e. museums, galleries... ). Second, this new approach invokes entrepreneurialism in two senses. On the one hand, bringing culture to the city includes entrepreneurialism as speculative construction of place in the sense that it attempts to promote and attract flows of mobile international capital and tourism through branding and the building of attractive city to investment and visitors. On the other hand, it includes Schumpeterian entrepreneurialism with the search of producing innovative spaces to keep innovativecreative industries in town (e.g. Bianchini, 1993). 


\section{Understanding Entrepreneurialism in 1990s}

The primary impact of the LA School, and of the new cultural geography, has made urban studies aware of the alleged "postmodern" conditions of contemporary cities. ${ }^{8}$ New trends in urban strategies have also prioritized culture in strategies for economic restructuring in many western cities (and, indeed, elsewhere too). In sum, the cultural turn has challenged the materialist-economic views of UPE, and its dominance within urban studies, by radically changing subjects of inquiry, and opening up new ways of analyzing and presenting new counter-strategies to mainstream political strategies (Leyshon and Lee, 2003).

Essentially, the cultural turn has brought about three main shifts. First, urban economic research has shifted away from the question of uneven development, which was central to UPE, and towards analyzing the role of culture in production distribution and consumption processes and the firm (G regson et al, 2001; Gottdiener, 1997; Zukin, 2003). Second, the cultural turn, coupled with a "spatial turn" in social sciences, has led to a vast literature with contributions to urban debates opening hundreds of new directions and approaches: from studies in gender, to ethnic networks, postcolonialism, sexual, performance, everyday life, virtual spaces... (Mitchell, 2000: 73; see also Low, 1999; Mitchell, 1999; Bridge and Watson, 2002; Eade and Mele, 2002). Third, the interest in culture has opened a Pandora's' box concerning the conceptualization of the cultureeconomy relationship, in particular around which variable is driving the other, in a broader manner than in economic geography (Shields, 1999; Vaiou, 1999).

These changes have obviously affected UPE, at first provoking defensive strategies (e.g Harvey, 1989b; Berman, 1989) and, ultimately, forcing these approaches to take account of the role of culture in political economy. O verall, the complexity and variety of approaches to the economy-culture articulation make it rather difficult to make a fair classification of all the possible approaches to the relation between culture and 
economy, although several attempts have been made (e.g. Crang, 1997; Le G alès, 1999; K Mitchell, 1999; Gregson, et al, 2001; Simonsen, 2001; Lees, 2002). However, I do not intend to add or repeat the exercise of mapping positions. On the contrary, in the next section, I will focus on how the cultural turn has constructively affected UPE.

\section{From urban to pre-theoretical cultural political economy}

While the discussions over how to conceptualise culture and economy are still lively and inconclusive, I would like to draw attention to an emerging but interesting work that is very relevant to our concerns which has as a departure point the city. This attempts to sweep away some of the prejudices of both culturalist and political economy positions but is still at what one might, following Althusser, call a pre-theoretical stage. This work can be situated on the terrain of cultural political economy. Although these efforts are still located in different ontological traditions, they all converge around a cultural perspective on the city that also takes material-economic matters seriously and/ or a political economy that recognizes the limits of purely materialistic accounts of the urban processes. Before taking a closer look at these works, I will explain the frame in which they appear.

\section{Breaking taboos in urban political economy}

Paradoxically, while some urban political economists across 1980s positioned themselves to defend urban studies against the influence of postmodernity (Harvey, 1989b; Berman, 1989), they obliged UPE to face the neglected issue of culture and come up with an alternative account. In this logic in the mid-1990s, Sharon Zukin's The Culture of Cities became a landmark work in attempting to disclose the cultural side to political economy. ${ }^{9}$ In this book, acknowledging the impact of the postmodern turn in settling the importance and multi-semiotic place of cultures in understanding the urban, she also 
rehabilitates the material basis of culture and Lefebrve's analysis of the material and immaterial production of space (1995: 289-94). On these bases Zukin understood culture as part of the economic base. Thus, in her studies of New York, she looked at the role of the symbolic eonomy (which merges both representational and material cultural production) in producing the city space. Central to her concerns was the question of for what and for whom culture works - a question that was at the core of the provocative essay of D on Mitchell in the same year of publication of Zukin's book (1995). Mitchell's core aim is to challenge the existence of culture as a thing, to stress the importance of asking which ideas of culture are mobilised and for what purpose. Although D on Mitchell's work has had only limited impact in geography as a whole (see Castree, 2004), it has been influential in the subfield of urban geography (Lake, 2003).

Alongside these developments within UPE there has been the recovery of the work of some urban political economists, who where marginalized by the orthodoxies of the 1970s. Three authors in urban studies - Benjamin, D ebord and Lefebvre - were reinterpreted and recovered through cultural geographers. Now, while access to their work in English through new editions or translations has contributed to this revival, their impact is mainly related to the primary place they gave to cultural processes in understanding urban processes compared to their neglect in the 1970s and 1980s. Several issues are worth highlighting from their complex, dense, and often contradictory, oeuvre.

First, the revival of Lefebvre may well rest, as McCann (1999: 168) notes, on his 'ability to link representation and imagination with the physical spaces of cities and to emphasize the dialectical relationship between identity and urban spaces.' In Lefebvre's work, both the material and the immaterial, structures and agencies got mixed up in the analysis of its triadic production of the urban space (Soja, 1989; Merrifield, 2002a). In this sense, Lefebvre has inspired several political economists to incorporate a more nuanced vision of the space into their analyses (e.g. Brenner, 2004; Wilson, 2004; 
Merrifield, 2002b; Swyngedouw, 1997; Soja, 1989). Second, Benjamin's work has been influential in raising concerns over the importance of everyday life for analysing the city and in adopting a differentiated, bottom-up perspective in opposition to universalistic positions (Merrifield, 2002a). In addition, as Savage (2000) notes, although it would be wrong to consider him as its main catalyst, Benjamin's views on the city as a text are indirectly reflected in the increasing importance of discourse analysis in. Third, D ebord's contemporary relevance has been re-affirmed in two key respects: (a) by the increasing importance of spectacles as mainstream urban strategy and the commodification of the urban (e.g. G otham, 2002; see below); and (b) by the revival of the situationist movement, as counter-strategies to these processes (Swyngedouw, 2002; Jappe, 1993).

\section{A pre-theoretical cultural political economy for the urban}

In sum, Zukin provided a first serious attempt to join cultural and political economy approaches, Mitchell offered a workable frame for inserting culture into political economy, and the recovery of the oeuvre of the enfants terribles of UPE presented a way to introduce political economy into culturalist takes. In this context, several empirical analyses of urban growth strategies in the US have looked critically at how the city is coconstituted by material and semiotic practices. Although these works are produced by scholars located in different theoretical currents and coming from different substantive research interests, all share a preoccupation with the relations between space, culture and political economy within the urban political economic restructuring of the last decades. Broadly, they can be inserted into four main lines of research (table 2).

\section{*** T able 2 around here $* * *$}


First, a primary focus of analysis has been the changed urban morphology brought to the city by political economic restructuring. In this sense, Zukin (1995) is a culmination of her earlier work on the changing landscape of US cities brought by the new artistic classes in (1988) and the "disneyification" of urban landscape (1991). From a historical geography perspective, D on Mitchell has moved from the role of labour and the erasing of its contribution in the production of Californian landscape in the turn of the $20^{\text {th }}$ century to the current period (1996a, 1998, 2003b). Closely related to this topic, Mitchell has also been investigated the production of public space, the exclusionary practices attached to it, and the role of law and rights in these processes which, he argues, defines the "post-justice" city (1996b, 1997, 2001, 2003a).

A second strand of research has focused on the increasing role of the "symbolic" and the leisure industry in the postmodern economic and political urban strategies (Zukin, 1995; Hannigan, 1998, G otham, 2002), and on contrasting the cultural attitudes of "new economy" growth coalitions (Nevárez, 2002; 2003). D eparting from an American urban geography tradition, two further strands have focused on the discursive formation of regeneration and economic strategies in North American cities. Thus, third, some research gravitates around the mobilisation of cultural discourses in entrepreneurial strategies of urban restructuring and the construction of race and ethnic difference in growth coalitions, and in particular with the depictions of blacks (McCann, 1999; Wilson, 2001a,b, 2004b, 2005), Hispanos (Wilson, 2004a, Wilson et al, 2003), and Chinese (K Mitchell, 1997a,b). And, fourth, there has been an increasing interest in the discursive formation of interurban competition both at the local level (McCann, 2002, Wilson and Wouters, 2003; Wilson and Mueller, 2004) and at the national/ global scale (Leitner and Sheppard, 1998, 1999; McCann, 2004,a,b).

These scholars in the US urban geography tradition have been attempting to combine the UPE tradition with the cultural turn without reifying the economic as solely 
cultural, or reducing the cultural to the result of the economic base. Perhaps it can be argued that their research is more cultural in focus rather than inspired by political economy (with the exception of McCann, 2002, 2003), and more centred in agency processes than structural ones. Concern with these processes in urban political economy is still limited and emerging and they may not become very popular. Nevertheless, I will argue that not only do they represent a serious attempt to re-insert culture in political economy far beyond representing a linguistic turn (see Lees, 2002) but that they can also be located as pre-theoretical cultural political economy.

\section{The cultural political economy beyond the city}

There have been many political economists who have taken a serious look at culture (e.g. Adorno, 2001; Lefebvre, 1991; Harvey, 1989a) and cultural theorists who have taken a serious look at the political economy (e.g. Benjamin, 1999; Williams, 1997; Eagleton, 2000). O ne might well ask what is new this time, then, to support my claim that contemporary political economists interested in culture are not just lone voices but belong to a broader, interdisciplinary movement towards cultural political economy? There are at least two good explanations which link them as well with a political economy tradition. First, departing from urban political economy, and acknowledging essential continuities between previous and contemporary urban processes, they have taken the cultural turn seriously. These takes on the cultural turn has been instrumental in reflect on the analytical categories that had been used in previous work on the urban and in political economy and re-elaborate a critique of the categories of political economy, thus returning to the roots of radical political economy. Thus CPE is clearly attempting to find a synergy between the economic and cultural spheres rather to onesidedly incorporate culture into political economy or vice versa. 


\section{Rethinking culture and economy, a critical take}

These authors are influenced not only by "classical" political economy but also by postmodern thinkers (figure 1). They thereby draw inspiration from ontological and epistemological perspectives other than radical postmodernism and orthodox political economy. They reject both the universalistic/ positivistic stand of the later and the radical relativism of the former. They accept both that reality exists but our knowledge is situated; and they regard social processes as co-constituted by material and semiotic practices. Thus, the key issue of CPE is to coherently insert the critique of the cultural turn into political economy in order to return to the origins of critical political economy: the critique of the bourgeoisie categories of political economy (as for example in Marx, 1973, 1976; see also Neocleous, 2004). In short, from the cultural turn, CPE incorporates the necessity to bring back to political economy topics such as discourse and identity formation, which are typically neglected by political economy. ${ }^{10}$ However, unlike "culturalist" approaches, CPE does not reduce everything to discourse; nor does it understand culture as superorganic force (cf. Mitchell, 1995). Rather it sees both the cultural and the economic, both immaterial and material processes, as co-constitutive of social relations. As indicated in figure 1, this emerging approach moves away from representational or materialist methodologies to develop a new account of the dialectical articulation of both the material and the semiotic as co-constitutive moments of economic practices.

\section{*** Figure 1 around here $* * *$}

In other words, they share the agenda that Jessop and Sum (2001: 94) claim to be the backbone of cultural political economy: 
A critical, self-reflexive approach to the definition and methods of political economy and to the inevitable contextuality and historicity of its claims to knowledge. Its rejects any universalistic, positivistic account of reality, denies the subject-object duality, allows for the co-constitutions of subjects and objects and eschews reductionist approaches to the discipline. However, in taking the "cultural turn," political economy should continue to emphasise the materiality of social relations and the constraints involved in processes that also operate "behind the backs" of the relevant agents. It can thereby escape the sociological imperialism of pure social constructionism and the voluntarist vacuity of certain lines of discourse analysis, which seem to imply that one can will anything into existence in and through an appropriately articulated discourse. "Cultural political economy" should recognise the emergent extra-discursive features of social relations and their impact on capacities for action and transformation.

As a nascent "post-discipline", CPE is still a wide open field, making it difficult to set definitive borders in what is and what is not CPE. Indeed, there are many possible ways to arrive at a CPE approach. I consider that $\mathrm{CPE}$ is not limited to introducing culture into the study of economic and political processes (or what Sayer, 2001 defines as CPE). Rather, I understand CPE (or pre-theoretical CPE) to be the result of moving from a one-sided emphasis on either the cultural constitution of politial economy, or on the political economy of culture, towards a critical altural political economy of social processes. This means that culture cannot be reduced to the economic and vice versa. Social processes are co-constituted by cultural, political and economic processes. 


\section{Mapping cultural political economy}

Incorporating these recent developments in urban geography, three main areas of interest have been central to the development of CPE (table 3): new spaces of governance, new economies, and restructuring and identity. First, under new spaces of governance, I group those lines of research that are interested in the continual re-shaping and production of new hegemonic orders and new regulatory spaces. They do not limit themselves to a "classical" political economy of such questions but go one step further by introducing new concerns (e.g. whose identities are reflected in new regions; the semiotic construction of state forms). Second, within the new economies category, I refer to the works of researchers interested in the shifting meaning of what counts as economy (e.g. economic imaginaries) and in the context of the increasing dominance of new economy and KBE narratives. Whilst these approaches usually give a lot of weight to the discursive formation of economic and political strategies, their analysis is certainly not limited to these matters. It also looks at the relations of these with material processes without reducing the economic to the cultural or the cultural economic (cf. Sayer, 2001; see also Gregson et al, 2001). Third, the label of restructuring identity combines analyses that focus on the production of identities and values. In this regard, these works are centred on the immaterial side of capitalism. Nonetheless, as opposed to radical postmodern positions, they do not neglect material processes, but analyse them as constituted for, through, with and in material realities.

\section{*** Table 3 around here}

In sum, the classification presented in table 3 captures four parallel lines of efforts in transforming political economy through appropriating insights made by both the cultural and the postmodern turn. In particular, there are two different ways to arrive 
to CPE. On the one hand, there are those who have incorporated the challenges and critiques that the postmodern and the cultural turns posed to political economy. Along these lines, there are the works grouped within "new spaces of governance," which all share the introduction of cultural methodologies (e.g. deconstruction, discourse analysis) into more "orthodox" political economy research questions (i.e. uneven development). Analogously, the restructuring and identity bloc comprises approaches that rethink issues largely neglected by political economy (e.g. agency, otherness, normativity). $\mathrm{On}$ the other hand, there are those who, accepting the necessity to think about the research questions brought by the cultural turn and ignored by political economy, reject the answer given from the former perspective. For instance, it is here that we find work on new economies, which acknowledges the hybridness and plurality of economic processes they do not reduce the economy to culture. In the same way, the theme of cultural-material production of space, reunites work that re-materialises urban cultural geography.

\section{Conclusions}

In sum, the developments presented in this paper do not offer a final solution to the articulation of economy and culture nor do they present political economy as a superior framework for understanding those processes. The scope of the paper has been tackling with culture and economy from a different angle. Moving the context of the discussion from the "nature" of the economy itself to how the articulation of economy and culture have been explores by urban political economists, I tried to engage with some emerging work that rather than taking simplistic perceptions of both perspectives they do critically look at them in order to move forward to a constructive and more nuanced vision of the urban. In short, throughout this discussion, I have tried to present the case for moving from urban political economy (as we know it) to the cultural political economy of the city, an approach that attempts to take seriously the importance of cultural processes, as 
the postmodern turn has provocatively highlighted, but that understand them to be closely linked to material political economy processes.

I am aware that CPE is not the only way to rematerialise culture in human geography (see Barnes, 2005). However, I would like to argue that the story of the shift from orthodox urban political economy to a dialectical rather than one-sided concern with culture holds some lessons that can be applied to the ongoing debates in economic, and more broadly human, geography. As urban geographers are accustomed to doing (Latham and McCormack, 2004), human geographers as a whole need to look outside the discipline. In this case, the transformation of political economy that has occurred through the adoption of a new view on culture reflects a search beyond the borders of established approaches and disciplinary fields to develop a trans-, or even, postdisciplinary perspective. Furthermore, recent UPE and CPE show how to enrich both urban geography and political economy traditions by selectively incorporating fruitful ideas from antagonist ontological positions.

\section{References}

Adorno, T. 2001: The culture industry: Selected essays on mass culture. In Berstein, J. M., editor, London: Routledge.

Agnew, J. 2005: Space:place. In Cloke, P. a. J., R, editor, Spaces of geographical thought, London: Sage, 81-96.

Amin, A. and N. Thrift 2000: What kind of economic theory for what kind of economic geography? A ntipode 32, 4-9.

Amin, A. and N. Thrift 2004: The Blackwell aultural economy reader. Oxford: Blackwell.

Amin, A. and N. Thrift 2005: What's Left? Just the future. A ntipode 37, 220-238.

Amin, A. and N. Thrift 2007a: On being political. Transactions of the Institute of British $\mathrm{G}$ eographers 32, 112-115

Amin, A. and N. Thrift 2007b: Cultural-economy and cities. Progress in H uman G eography 31, 43-161. 
Argent, N. and P. O'Neill, editors 2005: Theme issue: neoliberalism and the regions. $\mathrm{G}$ eographical research 43, 2-115.

Barnes, T. J. 2003: The 90s show: Culture leaves the farm and hits the streets. U rban G eography 24, 479-4.

Barnes, T. J. 2005: Culture:economy. In Cloke, P. and R. Johnston, editor, Spaces of geographical thought, London: Sage, 61-80.

Benjamin, W. 1999: The arcades project. London: Belknap Press.

Berman, M. 1989: A ll that is solid melts into air: The ex perienœ of modernity. New Y ork: Bernard and Schuster.

Bianchini, F. 1993: Remaking European cities: The role of cultural policies. In F., B. and M. Parkinson, editor, Cultural policy and urban regeneration, Manchester: Manchester University Press, 1-20.

Brenner, N. 2004: N ew state spaœes: U rban governanœ and the rescaling of statehood. O xford: Oxford University Press.

Brenner, N. and N. Theodore, eds. 2002: Spaces of neoliberalism: urban restructuring in $\mathrm{N}$ orth A merica and western E urope. Oxford: Blackwell.

Bridge, G. and S. Watson 2002: The Blackwell city reader. Oxford: Blackwell.

Catterall, B., editor 2005: Editorial to special issue. City 9, 1-2.

Castells, M. 1977: The urban question. London: Edward Arnold.

Castree, N. 2004: E conomy and culture are dead! Long live economy and culture. Progress in H uman G eography 28, 204-26.

Chatterton, P. 2000: Will the real creative city please stand up? City 4, 390-397.

Claval, P. 1998: H istorie de la géographie française de 1870 à nos jours. Paris: Nathan.

Coe, N. and Hess, M. 2007: G lobal production networks: challenges and debates. Paper prepared for the GPERG workshop, University of Manchester, 25-26 January 2007. available online at http:/ / www.sed.manchester.ac.uk/ geography/ research/ gpe/ downloads/ Manchester_Ja n07_positionpaper_final.pdf.

Coe, N.; Dicken, P. and M. Hess, M. 2008: Global production networks: realizing the potential. Journal of E conomic G eography, doi.10.1093/ jeg/ lbn002.

Crang, P. 1997: Introduction: Cultural turns and the (re)constitution of economic geography. In Roger, L. and J. Wills, editor, G eographies of economies, London: Arnold. 
Curry, J. and M. Kenney 1999: The paradigmatic city: Postindustrial illusion and the los angeles school. A ntipode 31, 1-29.

Davis, M. 1990: City of quartz. New Y ork: Basic Books.

Dear, M. 2000: The postmodern urban condition. O xford: Blackwell.

Dear, M. 2002: F rom Chicago to l.A .: M aking sense of urban theory. London: Sage.

Dear, M. 2003: The Los Angeles school of urbanism: An intellectual history. U rban G eography 24, 493-509.

du Gay, P. and M. Pryke 2002: C ultural economy: C ultural analysis and commercial life. London: Sage.

Eade, J. and C. Mele 2002: U nderstanding the city: Contemporary and future perspectives. Oxford: Blackwell.

Eagleton, T. 2000: The idea of alture. London: Routledge.

Fairclough, N. 2000: Language and neoliberalism. D isourse and Society 11, 147-8.

Florida, R. 2002: The rise of the creative dass and how it's transforming work, life, community and everyday life. New Y ork: Basic Books.

Gibson, C. and Kong, L. 2005: Cultural economy: a critical review. Progress in H uman $\mathrm{G}$ eography 29, 541-561.

Gibson-G raham, J. K. 1996: The end of capitalism (as we knew it). O xford: Blackwell.

Gibson-G raham, J. K. 2003: An ethics of the local. Rethinking Marxism 15, 49 - 74.

Gibson-G raham, J. K., S. A. Resnick and W. D. Wolf 2000: Class in its others.

Minneapolis: University of Minnesota Press.

Gibson-Graham, J. K., S. A. Resnick and W. D. Wolf 2001: Re/ presenting class: E ssays in postmodern M arxism. D urham, NC: Duke University Press.

Gómez, M. V. 1998: Reflective images: The case of urban regeneration in Glasgow and Bilbao. International Journal of U rban and Regional Research 22, 106-21.

Gómez, M. V. and González, S. 2001: A Reply to Beatriz Plaza's 'The GuggenheimBilbao Museum Effect. International Journal of U rban and Regional Research 25, 898-900.

Goodwin, M. 2004: Recovering the future: a post-disciplinary perspective on geography and political economy. In Cloke, P., P. Crang, and M. Goodwin, editors, E nvisioning human geographies. London: Arnold, 65-80.

Gotham, K. F. 2002: Marketing Mardi Gras: Commodification, spectacle and the political economy of tourism in New O rleans. U rban Studies 39, 1735-56. 
G otham, K. F. 2005: Tourism from above and below: Globalization, localization and New Orleans's Mardi Gras. International Journal of U rban and Regional Research 29, 309-26.

Gottdiener, M. 1997: The theming of A merica: D reams, visions and commercial spaces. Boulder, Col.: Westview Press.

Gregson, N., K. Simonsen and D. Vaiou 2001: Whose economy for whose culture? Moving beyond oppositional talk in European debate about economy and culture. A ntipode 33, 616-46.

Hall, T. and P. Hubbard 1998: The entrepreneurial city. G eographies of politics, regime and representation. Chichester: John Wiley and Sons.

Hannigan, J. 1998: Fantasy city: Pleasure and profit in the post-modern metropolis. New York: Routledge.

Harvey, D . 1973: Sodial justioe and the city. London: Edward Arnold.

Harvey, D. 1989: The condition of postmodernity. Oxford: Blackwell.

Harvey, D. 1989: From managerialism to entrepreneurialism: The transformation of urban governance in late capitalism. G eografisk a A nnaler B 71, 3-17.

Harvey D . 2006: The geographies of critical geography. Transactions of the Institute of British G eographers 31, 409-412.

Hess, M. and Y eung, W-C. 2006: G uest editorial: wither global production networks in economic geography: past present and future. E nvironment and Planning A 38, 1193-1204.

Holman, O. 2004: Integrating peripheral Europe: The different roads to "security and stability" in southern and central Europe. Journal of International Relations and D evelopment 7, 208-36.

Hudson, R. 2004: Conceptualizing economies and their geographies: Spaces, flows and circuits. Progress in H uman G eography 28, 447-471.

Hudson, R. 2005a: Cultural political economy: Re-thinking relations between culture and economy. Paper presented at the "C ulture T urn" in Political E conomy: D iscourses and Imaginaries, $2^{\text {mi }}$ Cultural Political $\mathrm{E}$ conomy W ork shop, Lancaster 28 June.

Hudson, R. 2005b: E conomic G eographies: Ciraits, Flows and Spaos. London, Sage.

Hudson, R. 2006: On What's Right and Keeping Left: Or Why Geography Still Needs Marxian Political Economy A ntipode 38, 374-395.

Jameson, F. 1981: Postmodernism: Or, the aultural logic of late capitalism. London: Verso.

Jappe, G. 1999: G uy D ebord. Berkeley: University of California Press.

Jencks, C. 1992: The post-modernism agenda. In Jencks, C., editor, Thepost-modern reader, London: Academy, 10-39. 
Jencks, C. 1993: H eteropolis: L os A ngeles, the riots, and the strange beauty of heteroarchitecture. New York: St. Martin's.

Jessop, B. 1998: The enterprise of narrative and the narrative of enterprise: Place marketing and the entrepreneurial city. In Hall, T. and P. Hubbard, editor, The entrepreneurial city. $G$ eographies of politics, regime and representation, Chichester: John wiley and Sons, 77-99.

Jessop, B. 2000: The crisis of the national spatio-temporal fix and the tendential ecological dominance of globalizing capital. International Journal of $U$ rban and Regional Research 24, 323-60.

Jessop, B. 2002: The future of the capitalist state. Cambridge: Polity.

Jessop, B. 2004: Cultural political economy, the knowledge-based economy, and the state. In Barry, A. and D. Slater, editor, The technological economy, London: Routledge.

Jessop, B. 2005: Cultural political economy, the knowledge-based economy, and the state. In Slater D. and A. Barry, editors, The T echnological E conomy. Routledge, London, 144-166.

Jessop, B. 2007: Statepower. Cambridge: Polity.

Jessop, B. and O oesterlynck, S. 2007: Cultural political economy: on making the cultural turn without falling into soft economic sociology, $\mathrm{G}$ eoforum, doi:10.1016/ j.geoforum.2006.12.008.

Jessop, B. and N. L. Sum 2001: Pre-disciplinary and post-disciplinary perspectives. N ew Political E conomy 6, 89-101.

Jessop, B. and N. L. Sum 2001: The Cultural turn in economics: T owards a cultural political economy. Aldershot: Edward Elgar, in press.

Jonas, A. G. and D. Wilson 1999: The city as a growth machine: Critical reflections two decades later. In Jonas, A. G . and D. Wilson, editor, The urban growth machine - critical perspectives two decades later, Albany: SUNY, 3-18.

Jonas, A. G . and D. Wilson 1999: The urban growth machine: C ritical perspectives two decades later. Albany: SUNY.

Jones, M. 2008: Recovering a sense of political economy, Political G eography, doi:10.1016/ j.polgeo.2008.03.003.

Jones, M. and G. MacLeod 2004: Regional spaces, spaces of regionalism: Territory, insurgent politics and the english question. Transactions of the Insititute of British $\mathrm{G}$ eographers 29, 433-52.

Keil, R. 1998: L os A ngeles: G lobalisation, urbanisation and social struggles. Chichester: Wiley.

Lake, R. W. 2003: The power of culture and the culture of power in urban geography in 
the 1990s. U rban G eography 24, 461-464.

Landry, C. 2000: The creative city, a toolk it for urban innovators. London: Earthscan.

Lash, S. and J. Urry 1994: E conomies of signs and spaces. London: Sage.

Latham, A. and M. P. McCormack 2004: Moving cities: Rethinking the materialities of urban geographies. Progress in H uman G eography 28, 701-24.

Le G alés, P. 1999: Is political economy still relevant to study the culturalization of cities? E uropean U rban and Regional Studies 6, 293-302.

Lee, R. 2006: The ordinary economy: tangled up in values and geography? Transadions of the Institute of British $\mathrm{G}$ eographers 31, 413-432.

Lees, L. 2002: Rematerializing geography: The "new" urban geography. Progress in H uman G eography 26, 101-12.

Lefebvre, H. 1991: Theproduction of space. Oxford: Blackwell.

Leitner, H. 1990: Cities in pursuit of economic growth. The local state as entrepreneur. Political G eography Q uarterly 9, 146-70.

Leitner, H. and E. Sheppard 1998: Economic uncertainty, inter-urban competition and the efficacy of entrepreneurialism. In Hall, T. and P. Hubbard, editor, The entrepreneurial aty. G eographies of politics, regime and representation, Chichester: John Wiley and Sons, 286307.

Leitner, H. and E. Sheppard 1999: Transcending inter-urban competition: Conceptual issues, and policy alternative in the European Union. In Jonas, A. G. and D. Wilson, editor, The urban growth machine: Critical perspectives twenty years later, Albany: SUNY, 227-46.

Leitner, H., J. Peck and E. S. Sheppard 2007: Contesting neoliberalism: urban frontiers. New York: Guilford.

Leyshon, A. and R. Lee 2003: Introduction: Alternative economic geographies. In Leyshon, A. and R. Lee, editors A lternative economic spaces, London: Sage, 1-26.

Low, S. M. 1999: Theorising the city: The new urban anthropology reader. New Brunswick, NJ: Rutgers University Press.

Marchand, M. H. 2004: Contesting the free trade area of the Americas: Invoking a Bolivarian geopolitical imagination to construct an alternative regional project and identity. Cultural Political E conomy W ork ing Paper 8,

Martin, R., \& P. Sunley, P. 2001: 'Rethinking the 'economic' in economic geography: broadening our vision or losing our focus? A ntipode 33, 148-161.

Marx, K. 1973: G rundisse London: Penguin.

Marx, K. 1976: Capital, a critique of political economy, vol. I. London: Penguin. 
McCann, E. 1999: Race, protest and public space: Contextualizing Lefebvre in the U.S. City. A ntipode 32,

McCann, E. 2002: The cultural politics of local economic development: Meaning-making, place-making, and the urban policy process. $\mathrm{G}$ eoforum 33, 385-98.

McCann, E. 2003: Framing space and time in the city: Urban policy and the politics of spatial and temporal scale. Journal of U rban A ffairs 25, 159-78.

McCann, E. 2004: "best places:" interuban competition, quality of life and popular media discourse. U rban Studies 41, 1909-30.

McCann, E. 2004: Urban political economy beyond the "global city". U rban Studies 41, 2315-34.

McNeill, D . 2003: Mapping the european urban left: The Barcelona's experience. A ntipode 35, 74-94.

Merrifield, A. 2000: Henri Lefebvre: A socialist in space. In Crang, M. and N. Thrift, editor, Think ing spaœ, London: Routledge, 167-82.

Merrifield, A. 2002: D ialectical urbanism, social struggles in the capitalist city. New Y ork: Monthly Review.

Merrifield, A. 2002: M etromarx ism: A Marx ist tale of the city. London: Routledge.

Merrifield, A. 2004: D ebord's world. E nvironmental and Planning D 22, 425-28.

Mitchell, D . 1995: There_5426?s no such thing as culture: Towards a reconceptualisation of the idea of culture in geography. Transactions of the Insititute of British $\mathrm{G}$ eographers 19, 102116.

Mitchell, D. 1996: The lie of the land: M igrant work ers and the C alifornia landscape. Minneapolis: University of Minnesota Press.

Mitchell, D . 1996: Political violence, order, and the legal construction of public space: Power and the public forum doctrine. U rban G eography 17, 152-78.

Mitchell, D . 1997: The annihilation of space by law: The roots and implications of antihomeless laws. A ntipode 29, 303-35.

Mitchell, D . 1998: The scales of justice: Localist ideology, large-scale production and agricultural labor's geography of resistance in 1930s california. In Herod, A., editor, 0 rganizing the landscape: $\mathrm{G}$ eographical perspectives on labor unionism, Minneapolis: University of Minnesota Press, 159-94.

Mitchell, D . 2000: Cultural geography: A critical introduction. Oxford: Blackwell.

Mitchell, D . 2001: Postmodern geographical praxis? The postmodern impulse and the war against the homeless in the post-justice city. In Minca, C., editor, Postmodern geography: Theory and praxis, London: Routledge, 57-92. 
Mitchell, D . 2003: California living, California dying: D ead labor and the political economy of landscape. In Anderson, K., S. Pile and N. Thrift, editor, $\mathrm{H}$ andbook of cultural geography, London: Sage, 233-48.

Mitchell, D . 2003: The right to the city, social justice and the fight for public spac. London: Routledge.

Mitchell, K. 1997: Conflicting geographies of democracy and the public sphere in vancouver, b.C. Transactions of the Institute of British $\mathrm{G}$ eographers 22, 162-79.

Mitchell, K. 1997: Transnational discourse: Bringing geography back in. A ntipode 29, 10114.

Mitchell, K. 1999: What culture got to do with it?. U rban G eography 20, 667-77.

Mollenkopf, J. 1983: The C ontested City, Princeton: Princeton University Press.

Neocleous, M. 2004: Bloody capital and dead labour: Cultural studies or the critique of political economy. C ultural Political E conomy W orking Paper, 5.

Nevárez, L. 2002: Efficacy or legitimacy of community power? A reassessment of corporate elites in urban studies. In Eade, J. and C. Mele, editor, U nderstanding the city: C ontemporary and future perspectives, London: Routledge, 379-96.

Nevárez, L. 2003: N ew money, niœ town: H ow capital work s in the new urban economy. London: Routledge.

O 'connor, D. 1998: Popular culture, cultural intermediaries and urban regeneration. In Hall, T. and P. Hubbard, editor, The entrepreneurial city. G eographies of politics, regime and representation, Chichester: John Wiley and Sons, 225-39.

Overbeek, H. 2000: Transnational historical materialism: Theories of transnational class formation and world order. In Palan, R., editor, G lobal political economy: C ontemporary theories, London: Routledge, 168-83.

Overbeek, H. 2003: The political economy of E uropean employment: E uropean integration and the transnationalization of the (un)employment question. London: Routledge.

Overbeek, H. 2004: Transnational class formation and concepts of control: Towards a genealogy of the amsterdam project in international political economy. Journal of International Relations and D evelopment 7, 113-41.

Peterson, P. 1981: City limits. Chicago: University of Chicago Press.

Plaza, B. 1999: The Guggenheim-Bilbao museum effect: A reply to Mańa V Gómez' "Reflective images: The case of urban regeneration in Glasgow and Bilbao". International Journal of U rban and Regional Research 23, 589-92.

Porter, M. 1995: The Competitive Advantage of Inner City. H arvard Bussiness Review 74, 55-71. 
Savage, M. 2000: Walter Benjamin's urban thought: A critical analysis. In Crang, M. and N. Thrift, editor, Thinking spaœ, London: Routledge, 33-53.

Savage, M., A. Warde and K. Ward 2003: U rban sociology, capitalism and modernity. Basingstoke: Palgrave MacMillan.

Sayer, A. 2000: Moral economy and political economy. Studies in Political E conomy 61, 79104.

Sayer, A. 2001: A critical cultural political economy. A ntipode 33, 687-708.

Sayer, A. 2005: The moral significanœ of class. Cambridge: Cambridge University Press.

Scott, A. J. 2001: The cultural economy of dities. London: Sage.

Scott, A. J. and E. Soja 1996: The city: L os A ngeles and urban theory at the end of the twentieth cntury. Berkeley: University of California Press.

Shields, R. 1999: Culture and the economy of cities. E uropean U rban and Regional Studies 6, 303-11.

Simonsen, K. 2001: Space, culture and economy: A question of practice. $G$ eografiska A nnaler B 83, 41-52.

Smith, N. 2005: What's Left? Neo-critical geography, or the flat pluralist world of business class. A ntipode 37, 887-99.

Soja, E. 1989: Postmodern geographies: The reassertation of space in critical social theory. London: Verso.

Soja, E. 2000: Postmetropolis, Critical Studies of Cities and Regions. Oxford: Blackwell.

Storper, M. 1997: The Regional W orld: Territorial D evelopment in a G lobal W orld. London: Guilford.

Storper, M. 2001: The Poverty of Radical Theory Today: From the False Promises of Marxism to the Mirage of the Cultural Turn. International Journal of U rban and Regional Research 25, 155-79.

Sorkin, M. 1992: V ariations on a theme park: scenes from the new A merican aity. New York: Noonday.

Sum, N. L. 2000: G lobalization and its "other(s):" three "new kinds of orientalism" and the political economy of trans-border identity. In Hay, C. and D. Marsh, editor, D esmystifying globalization, London: Macmillan, 111-32.

Sum, N. L. 2004: From "integral state" to "integral world economic order" . Cultural Political E conomy W orking Paper 7. 
Sum, N. L. 2008: A cultural political economy of competitiveness: knowledge brands and knowledge technologies. Presented paper at the ESRC Research Seminar Series "Changing Cultures of Competitiveness", Lancaster University.

Swyngedouw, E. 1997: The spectre of the phoenix, reflections on the contemporary urban condition. In Bosma, $\mathrm{K}$. and $\mathrm{H}$. Hellinga, editor, M astering the city, Rotterdam: Architecture Institute, 104-21.

Swyngedouw, E. 2002: The strange respectability of the situationist city in the society of the spectacle. International Journal of U rban and Regional Research 26, 153-65.

Swyngedouw, E. and M. Kaïka 2003: The making of "glocal" urban modernities. City 7, 5-22.

Vaiou, D. 1999: Whose culture and economy in what Europe? E uropean U rban and Regional Studies 6, 314-16.

Van der Pilj, K. 1998: Transnational dasses and international relations. London: Routledge.

Williams, R. 1997: Problems in materialism and culture London: Verso.

Wilson, D . 2001: Colouring the city: "black-on-black violence" and liberal discourse. Tijdschrift voor E conomische en Sociale G eografie 92, 261-78.

Wilson, D . 2004: Inventing black-on-black violence: D iscourse, spaœ, representation. Syracuse: Syracuse University.

Wilson, D . 2004: Making historic preservation in Chicago: Space, discourse, and neoliberalism. Space and Polity 8, 43-59.

Wilson, D . 2005a: Toward a contingent urban neoliberalism U rban geography 25, 771-83.

Wilson, D . 2005b: Cities and raœ: The new A merican black ghetto. London: Routledge.

Wilson, D. and T. Mueller 2004: G rowth coalitions, language, and metaphorical deployment in st. Louis. Professional G eographer 56, 282-94.

Wilson, D . and J. Wouters 2003: Spatiality and growth discourse: The restructuring of america's rust belt cities. Journal of U rban A ffairs 25, 123-39.

Wilson, D., J. Wouters and D. Grammenos 2003: Successful protect-community discourse: Spatiality and politics in chicago's pilsen neighbourhood. E nvironment and Planning A 39, 1173-90.

Zukin, S. 1980: A decade of the new urban sociology. Theory and Society 9, 575-601.

Zukin, S. 1988: L oft living: C ulture and capital in urban change London: Radius.

Zukin, S. 1991: Landscapes of power: From D etroit to Disney world.

Zukin, S. 1995: The culture of cities. Oxford: Blackwell. 
Zukin, S. 2003: Point of purchase: H ow shopping changed american culture. London: Routledge. 


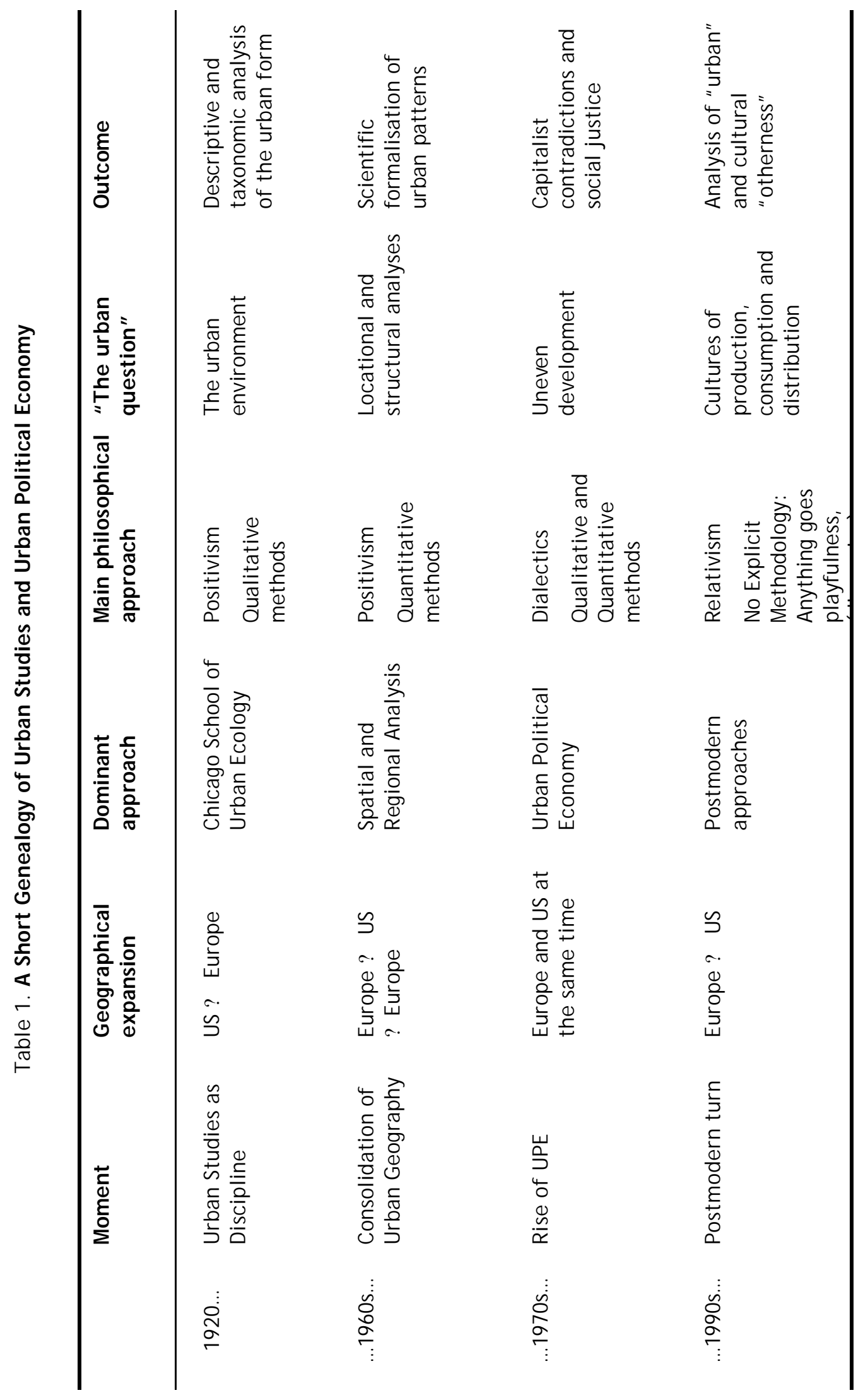




\section{Table 2. From urban to cultural political economy}

\begin{tabular}{ll}
\hline The CPE of... & Topics \\
\hline $\begin{array}{l}\text { Urban morphology of } \\
\text { restructuring }\end{array}$ & The cultural-material production of urban space \\
$\begin{array}{l}\text { New and symbolic } \\
\text { Economies }\end{array}$ & $\begin{array}{l}\text { "Symbolic economy", philanthropy and the leisure } \\
\text { industry in the postmodern economic and political } \\
\text { urban strategies }\end{array}$ \\
$\begin{array}{l}\text { Entrepreneurialism and } \\
\text { Ethnicity }\end{array}$ & $\begin{array}{l}\text { Mobilisation of cultural discourses in entrepreneurial } \\
\text { strategies of urban restructuring and the construction } \\
\text { of race and ethnic difference in growth coalitions }\end{array}$ \\
$\begin{array}{l}\text { The Construction of } \\
\text { Interurban Competition }\end{array}$ & Material-discursive formation of interurban competition \\
\hline
\end{tabular}


Table 3. Themes in Cultural Political Economy

\begin{tabular}{|c|c|c|c|c|}
\hline Themes & Sub-themes & Focus & Indicative authors & Main Influences \\
\hline \multirow{6}{*}{$\begin{array}{l}\text { New Spaces } \\
\text { of } \\
\text { Governance }\end{array}$} & \multirow[t]{2}{*}{ New Global Spaces } & \multirow[t]{2}{*}{$\begin{array}{l}\text { Integral world economic } \\
\text { orders }\end{array}$} & Sum $(2004,2008)$ & $\begin{array}{l}\text { Gramsci, Foucault, Regulation } \\
\text { Theory }\end{array}$ \\
\hline & & & $\begin{array}{l}\text { Overbeek (2003), Holman } \\
\text { (2004) }\end{array}$ & $\begin{array}{l}\text { Gramsci, Marx, Wallerstein, } \\
\text { Regulation theory }\end{array}$ \\
\hline & New State Spaces & $\begin{array}{l}\text { New state forms and its } \\
\text { rescaling }\end{array}$ & J essop $(2000,2002,2007)$ & $\begin{array}{l}\text { Marx, Regulation Theory, } \\
\text { Gramsci, Critical Discourse } \\
\text { Analysis, Poulantzas, Strategic } \\
\text { Relational Approach (SRA) }\end{array}$ \\
\hline & $\begin{array}{l}\text { New Regional } \\
\text { Spaces }\end{array}$ & English regionalism & Jones \& MacLeod (2004) & $\begin{array}{l}\text { Regulation Theory, SRA, } \\
\text { Critical Discourse Analysis, } \\
\text { Critical Realism }\end{array}$ \\
\hline & \multirow[t]{2}{*}{$\begin{array}{l}\text { Interurban } \\
\text { Competition }\end{array}$} & $\begin{array}{l}\text { Discourses of urban growth } \\
\text { in US }\end{array}$ & \multirow{2}{*}{$\begin{array}{l}\text { McCann (2004a, b) } \\
\text { Wilson and Wouters, } \\
\text { (2003) Wilson et al (2004) } \\
\text { Leitner \& Sheppard (1998; } \\
\text { 1999) }\end{array}$} & $\begin{array}{l}\text { NUP, SRA (McCann), discourse } \\
\text { analysis, Lefebvre }\end{array}$ \\
\hline & & Interurban networks & & $\begin{array}{l}\text { NUP, network theory, discourse } \\
\text { analysis }\end{array}$ \\
\hline \multirow{7}{*}{$\begin{array}{l}\text { New } \\
\text { Economies }\end{array}$} & \multirow{3}{*}{$\begin{array}{l}\text { Symbolic } \\
\text { Economies }\end{array}$} & Symbolic urban economy & Zukin (1995) & cultural \& economic sociology \\
\hline & & $\begin{array}{l}\text { Leisure and urban } \\
\text { strategies }\end{array}$ & Hannigan (1998) & cultural \& economic sociology \\
\hline & & $\begin{array}{l}\text { City spectacles and } \\
\text { entrepreneurial strategies }\end{array}$ & Gotham (2002; 2005) & $\begin{array}{l}\text { Political economy, urban } \\
\text { sociology, Debord }\end{array}$ \\
\hline & \multirow[t]{4}{*}{$\begin{array}{l}\text { New economic } \\
\text { spaces }\end{array}$} & $\begin{array}{l}\text { Economic imaginaries of } \\
\text { the Knowledge Base } \\
\text { Economy (KBE) and } \\
\text { discourses of KBE }\end{array}$ & $\begin{array}{l}\text { Jessop (2004a,b, 2005) } \\
\text { Jessop \& Ooesterlynck } \\
\text { (2007) } \\
\text { Fairclough }(2000)\end{array}$ & $\begin{array}{l}\text { Marx, Regulation Theory, } \\
\text { Gramsci, Critical Discourse } \\
\text { Analysis }\end{array}$ \\
\hline & & $\begin{array}{l}\text { Global Production } \\
\text { Networks }\end{array}$ & $\begin{array}{l}\text { Coe et al. (2008), Coe } \& \\
\text { Hess (2007), Hess \& Yeung } \\
(2006),\end{array}$ & $\begin{array}{l}\text { Global value chains, networks } \\
\text { and embeddedness, actor-- } \\
\text { network theory, new political } \\
\text { economy of scale }\end{array}$ \\
\hline & & Circuits of value & Hudson (2005) & Marx, political economy \\
\hline & & & Lee (2006) & $\begin{array}{l}\text { Relational economic geography, } \\
\text { semiotic analysis, } \\
\text { postcolinalism }\end{array}$ \\
\hline \multirow[t]{8}{*}{$\begin{array}{l}\text { Restructuring } \\
\text { and Identity }\end{array}$} & \multirow[t]{3}{*}{$\begin{array}{l}\text { Capitalist Crisis } \\
\text { and Identity }\end{array}$} & $\begin{array}{l}\text { The Asian Crisis and } \\
\text { identity formation } \\
\text { The American Free Trade } \\
\text { Area and the construction } \\
\text { of Americanism }\end{array}$ & $\begin{array}{l}\text { Sum (2000) } \\
\text { Marchand (2004) }\end{array}$ & $\begin{array}{l}\text { Gramsci, Foucault, Regulation } \\
\text { Theory } \\
\text { Feminism, Postmodernit y, } \\
\text { Foucault }\end{array}$ \\
\hline & & $\begin{array}{l}\text { Spatial constitution of } \\
\text { Class }\end{array}$ & $\begin{array}{l}\text { Gibson-Graham, Resnick } \\
\text { and Wolf }(2000,2001)\end{array}$ & \\
\hline & & & $\begin{array}{l}\text { Van der Pij। }(1998), \\
\text { Overbeek }(2000,2004)\end{array}$ & $\begin{array}{l}\text { Gramsci, Marx, Wallerstein, } \\
\text { Regulation theory }\end{array}$ \\
\hline & \multirow[t]{3}{*}{$\begin{array}{l}\text { Ethnicity \& } \\
\text { Entrepreneurialism }\end{array}$} & \multirow[t]{2}{*}{$\begin{array}{l}\text { Depiction of Black and } \\
\text { Hispanos ghettos }\end{array}$} & McCann (1999) & $\begin{array}{l}\text { NUP, discourse analysis, } \\
\text { Lefebvre, SRA }\end{array}$ \\
\hline & & & $\begin{array}{l}\text { Wilson (2001a, b, 2004b, } \\
\text { 2005; Wilson et al, 2003) }\end{array}$ & $\begin{array}{l}\text { NUP, discourse analysis, } \\
\text { Lefebvre }\end{array}$ \\
\hline & & $\begin{array}{l}\text { Transnational Chinese } \\
\text { depictions }\end{array}$ & K Mitchell $(1997 a, b)$ & $\begin{array}{l}\text { NUP, discourse analysis, } \\
\text { cultural geography }\end{array}$ \\
\hline & \multirow[t]{2}{*}{ Moral Economy } & \multirow[t]{2}{*}{$\begin{array}{l}\text { Values and ethics of } \\
\text { capitalism }\end{array}$} & Sayer (2000; 2005) & $\begin{array}{l}\text { Classical Political Economy, } \\
\text { Marxism, Critical Realism }\end{array}$ \\
\hline & & & $\begin{array}{l}\text { Gibson Graham (1996, } \\
\text { 2003) }\end{array}$ & Marxism, Feminism, Foucault \\
\hline
\end{tabular}


Figure 1. Comparing CPE with the Cultural Turn and Political Economy

Cultural Turn
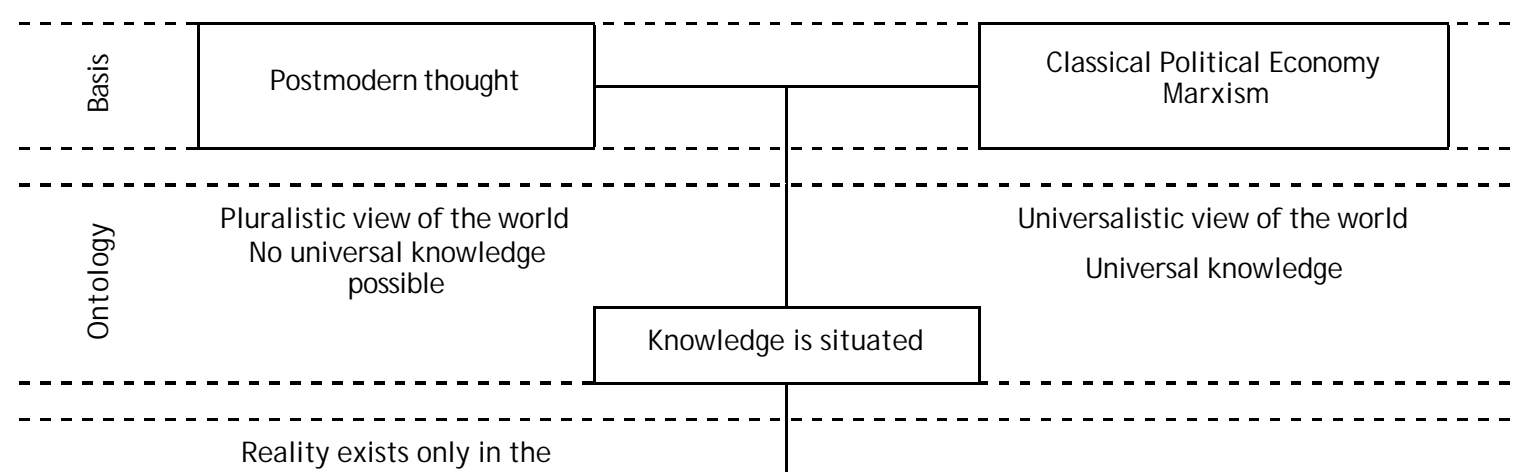

subjective constructivism)

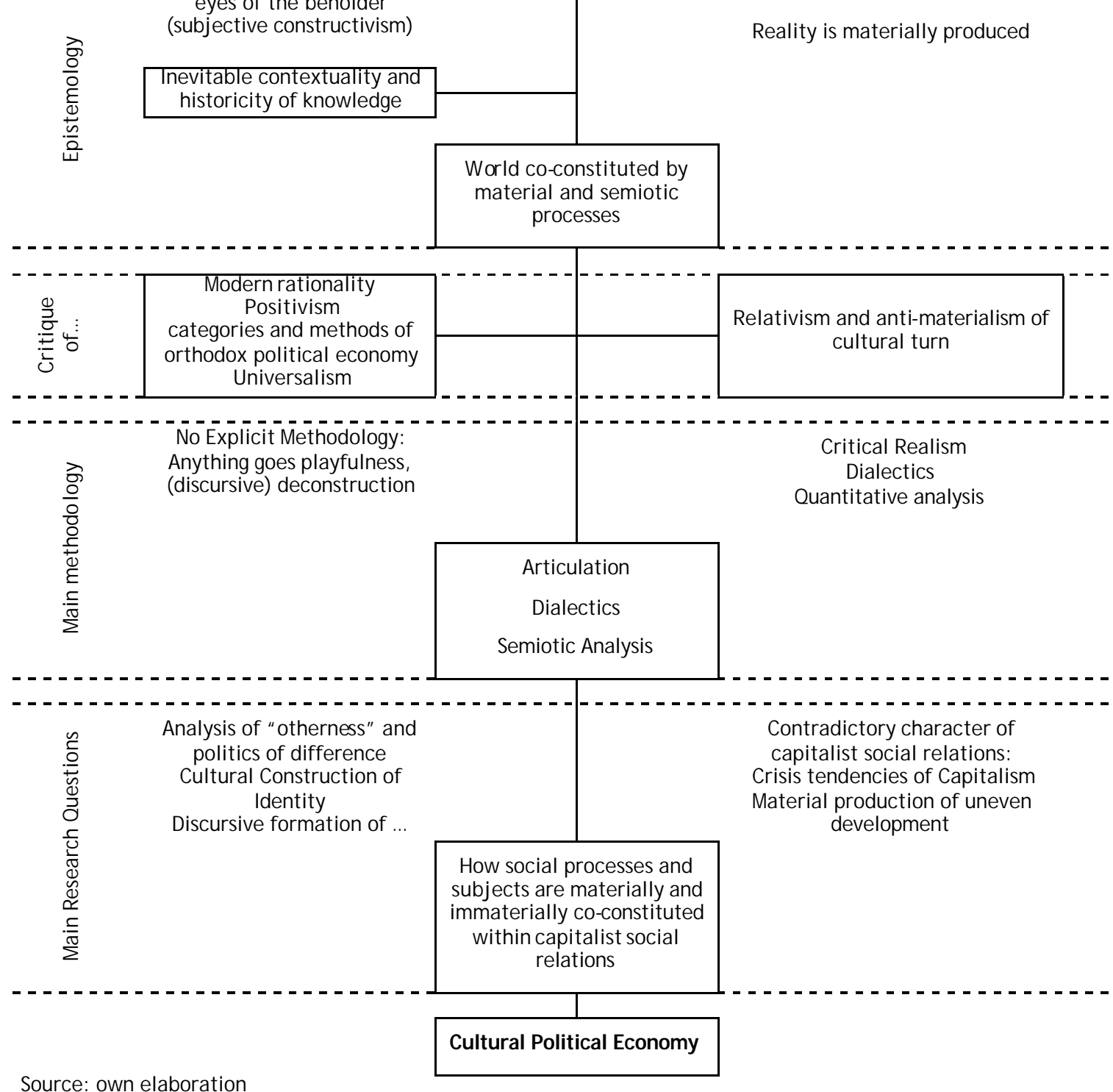


Endnotes 


\section{Endnotes}

1 The "cultural" turn in the social sciences of the 1980s/1990s was based on the widespread denunciation of the economism of political economy. This turn is not equivalent to the "postmodern" one, which signalled a deeper break with modernism. Nonetheless, the latter deeply informed the former, and culturalism and anti-economism are at the basis of the postmodern turn. Thus, although not reducible one to each other, both have had an intertwined impact on political economy approaches.

${ }^{2}$ This paper is limited to discussions within Anglophone scholarship. Hudson (2005) - in my view - rightly points out that the culture-economy articulation has been a northern European (and North American by extension) obsession. Space here precludes an investigation into why this might be so.

${ }^{3}$ Although cultural economy has been traditionally equated with the study of cultural industries, increasingly the term has a much broader meaning. For instance, Amin and Thrift (2004: xviii) define cultural economy as the post-discipline 'concerned with the processes of social and cultural relations that go to make up what we conventionally term the economic' (see also Amin and Thrift, 2007b; Gibson and Kong, 2005; Du Gay and Pryke, 2002; G regson, et al, 2001; Scott, 2001; Lash and Urry, 1994).

4 Though the debate has been set within economic geography, as Castree (2004) points out, looking at the recent handbooks in economic geography and reviewing the professional journals, the debate has had very limited success in prompting changes in the structure and agenda within economic geography. The reason behind has been the rediscovery of geography by economists. In what can be called an "economics turn," an important and 
increasing part of the new economic geography landscape in general has been occupied by neoclassical economic geographers, who have hardly intervened in this particular debate. This is no surprise, since neoclassic economic geography is based on the transhistorical character of both market relations and homo economicus, hence "the economic" can be isolated from "the cultural" in their analysis.

${ }^{5}$ However, the entrepreneurial turn has been studied from different approaches, a part from UPE. From neo-classical approaches see Peterson (1981); Porter (1995). For a less economic deterministic point of view see Mollenkopf (1983). For a review see Leitner, (1990).

${ }^{6}$ Although UPE was dominated by entrepreneurialism it was not limited to it. In particular in the 1990s, UPE has been connecting entrepreneurial with other urban and supra-local processes (gentrification, public space, workfare state, etc.) and developed more generally to what is now termed neoliberal urbanism (Leitner et al., 2007; Wilson, 2005a; O'Neill and Argent, 2005; Catterall, 2005; Brenner and Theodore, 2002).

${ }^{7}$ By "Guggenheim effect" I refer to the spread of spectacular museums and cultural centres designed by famous architects as means of boosting local economies (e.g. The Lowry in Salford, Urbis in Manchester, Baltic Centre in Gateshead, etc.), and often legitimised by the "success" of Bilbao. Although the use of this kind of strategy existed long before than the opening of G hery's building in 1997, its impact on Bilbao's image and the flow of tourist visiting the landmark was claimed by the local and regional authorities and media as a palpable example of how cultural landmarks can change the fortunes of decadent cities (for a discussion on the actual effects see Gómez, 1998; Plaza, 1999; Gómez and González, 2001). 
${ }^{8}$ In contrast to other geographical sub-disciplines, neither postmodemism nor political economy have won hegemony in urban geography. There is no better example of that than the alleged Los Angeles school. Although some of his main figures are located in the middle of postmodern philosophical principles (e.g. Jencks, 1993; Dear, 2000), many others LA scholars have held more equidistant positions from postmodernism and political economy (e.g. Soja, 2000), others embraced more Marxists accounts (Davis, 1990; Keil, 1998), directly rejected both (Storper, 2001) or moved towards heterodox economics (Storper, 1997; Scott, 2001).

${ }^{9}$ Zukin was not the only one in looking at the cultural side of late capitalism (e.g. Jameson, 1981; Sorkin, 1992), and neither was she alone in looking for a middle ground position (e.g. Gottdiener, 1997; Hannigan, 1998), but her book has been very influential not only for framing routes for a CPE but also amongst UPE and cultural studies scholars.

${ }^{10}$ As regards discourses, orthodox political economy reduced them to merely part of the ideological sphere of a funcitionalist base-super-structure model. In respect to identity and subject formation, is an almost forgotten issue, although some key thinkers such as Gramsci did incorporate it into his analysis (see Jessop and Sum, 2005). 